\title{
Adiponectin Can Affect ER Signaling in Obese Breast Cancer Patients
}

\author{
Rana Jahanban Esfahlan ${ }^{1,2,3^{*}}$, Nosratollah Zarghami ${ }^{1,2}$, Samira Valiyari ${ }^{4}$, Hamed Farshbaf Kamel ${ }^{5}$, \\ Maryam Daneshvar $^{6}$, Ali Jahanban Esfahlan ${ }^{3,7}$, Majid Mobasseri $^{8}$, Kazem Nejati-Koshki ${ }^{2 *}$ \\ ${ }^{1}$ Radio Pharmacy Laboratory, Drug Applied Research Center, Tabriz, Iran; ${ }^{2}$ Department of Medical Biotechnology, Faculty of Ad- \\ vanced Medical Sciences, Tabriz University of Medical Sciences, Tabriz, Iran; ${ }^{3}$ Student Research Committee, Tabriz University of \\ Medical Sciences, Tabriz, Iran; ${ }^{4}$ Immonology Laboratory, Drug Applied Research Center, Tabriz, Iran; ${ }^{5}$ Department of Immunology, \\ Faculty of Medicine, Shahid Beheshti University of Medical Sciences, Tehran, Iran; ${ }^{6}$ Department of Medical Genetics, Tehran Uni- \\ versity of Medical Sciences, Tehran, Iran; ${ }^{7}$ Department of Pharmaceutical Biotechnology, Faculty of Pharmacy, Tabriz University of \\ Medical Sciences, Tabriz, Iran; ${ }^{8}$ Department of Internal Medicine, Division of Endocrinology and Metabolic Disorders, Imam Reza \\ Teaching Hospital, Tabriz University of Medical Sciences, Tabriz, Iran. \\ Email: \{*Nejati.K, ${ }^{*}$ rana.jahanban\}@gmail.com
}

Received December $1^{\text {st }}, 2011$; revised January $3^{\text {rd }}, 2012$; accepted January $18^{\text {th }}, 2012$

\begin{abstract}
Background: While the various antitumororal activities of adiponectin as an adipocyte-derived hormone well studied, it is speculated that there is a crosstalk between adiponectin and esterogen receptor (ER) signaling. To test this hypothesis we evaluate the possible correlation between serum level of adiponectin with two estrogen receptors (ER $\alpha$ and $\operatorname{ER} \beta$ ) gene expression in breast cancer patients. Methods: In this case-control study, 70 women with breast cancer participated with different grades of obesity ( 36 none obese, BMI $<25 \mathrm{~kg} / \mathrm{m}^{2}$ and 34 obese, BMI $\geq 25 \mathrm{~kg} / \mathrm{m}^{2}$ ). The mean age of Participants was $44.53 \mathrm{yr} \pm 1.79 \mathrm{yr}(21 \mathrm{yr}-70 \mathrm{yr})$.Serum level of adiponectin determined by ELISA. Following quantitative expression of estrogen receptors mRNA in tumor tissues was evaluated by Real-time PCR. Results: We find a significant reverse correlation between serum level of Adiponectin and ER $\alpha$ mRA $(r=-0.229, n=64, p=0.035)$ but no correlation was between adiponectin and $\operatorname{ER} \beta$ in samples $(\mathrm{p}=0.228)$. The lower adiponectin multiplied the odds of having higher $\mathrm{ER} \alpha$ mRNA level by a factor of $\mathrm{OR}=4.33,1.28-14.6,95 \%$ confidence interval (CI) as compared with those that displayed a moderate or higher serum level of adiponectin $(>7.02 \mathrm{ng} / \mathrm{ml})$. The same odds for next estrogen receptor, $\mathrm{ER} \beta$, was not greater than unity $(\mathrm{OR}=0.31,0.06-1.56,95 \% \mathrm{CI})$. Conclusion: According to the obtained results, it is speculated that as adiponectin can affect ERs gene expression, so affecting the steroid receptor signaling can be proposed as a new underling mechanism of action for this adipokine in breast cancer pathogenesis especially in obese ones.
\end{abstract}

Keywords: Breast Cancer; Adiponectin; Estrogen Receptors

\section{Introduction}

Breast cancer is the most common neoplasm in women [1]. Far now many studies revealed the connection between obesity and breast cancer risk [2-5]. One explanation for this association, is elevated circulating estrogen levels resulting from peripheral aromatization of androgens in the adipose tissue in obese postmenopausal women that can act as a mitogen and cause to development and progression of hormone dependant cancers [6]. Estrogen exert its effect in tissues through two receptors: Estrogen receptor $\alpha(\mathrm{ER} \alpha)$ and estrogen receptor $\beta(\mathrm{ER} \beta)$. The effect of these two receptors can be opposite. ER $\alpha$ has mitogennic properties and cause to proliferation of mammary cells, while ER $\beta$ exerts anti proliferative activities

*Corresponding authors. and can oppose and regulate ER $\alpha$ gene expression [7-9]. In normal breast $\operatorname{ER} \beta$ is the dominant estrogen receptor while, in cancerous breast the ratio of $\mathrm{ER} \alpha / \mathrm{ER} \beta$ increases and the expression of ER $\alpha$ gene is dominant $[10,11]$. Apart from role of estrogen and its receptors in pathogenesis of breast cancer, it is now recognized that the white adipose tissue (WAT) produces a variety of bioactive peptides, collectively termed "adipokines" $[12,13]$. Alteration of WAT mass in obesity, affects the production of most adipose secreted factors. Among the known adipocye-derived hormones, Adiponectin is unique from others $[12,14]$. While excess adipose tissue in obese subjects increase production of most of adipokines such as leptin, obese subjects have a lower serum level of adiponectin in comparison to their lean counterparts, moreover weigh loss can increase serum level of adiponectin 
$[3,15]$. Many in vitro studies revealed the anti-tumoral effects of this adipocytokine such as its anti-angiogenic, pro apoptotic, anti inflammatory and anti prolifrative activities that propose it as a potent tumor suppressor gene $[16,17]$. Recently it is proposed that there may be a crosstalk between this adipokine and estrogen receptor signaling [11,17], so the aim of this study was to determine the possible connection between serum level of adiponectin and $\operatorname{ER} \alpha$ and $\operatorname{ER} \beta$ gene expression in breast cancer tissues.

\section{Materials and Methods}

\subsection{Patients and Samples (Tissue and Serum)}

This work was a discriptional and cross sectional study. All samples were obtained from 70 women who underwent biopsy or mastectomy surgical operation at Tabriz Emam Reza Hospital from July 2009 till May 2010. The whole project has been carried out in Tabriz Drug Applied Research Center. The samples were examined histologically for the presence of tumor cells by a Pathologist. The patients met the following criteria: primary unilateral non metastatic breast carcinoma for which complete clinical, histological and biological data were available; and no radiotherapy or chemotherapy before surgery.

\subsection{Analysis of Serum Level of Adiponectin}

Plasma concentrations of adiponectin determined by means of commercially available quantitative sandwich enzymelinked immunosorbant assay (ELISA) kits (AdiponectinELISA E09, Germany). The sensitivity of this assay was $<0.6 \mathrm{ng} / \mathrm{ml}$. masked split specimens included within each batch were used to calculate the coefficient of variation (CV) within and between batches: the intra- and interassay CVs of this adipokine was below $6.7 \%$ and $4.7 \%$ for adiponectin, respectively.

\subsection{Preparation of Total RNA}

Approximately $100 \mathrm{mg}$ of tissue for RNA extraction by means of RNAX reagents previously described by jahanban et al. [10]. The quality of RNA samples ensured by electrophoresis in an agarose gel followed by ethidium bromide staining, where the $18 \mathrm{~S}$ and $28 \mathrm{~S}$ RNA bands could be visualized under UV light. Quantification of RNA was performed in duplicate by spectrophometry at $260 \mathrm{~nm}$.

\section{4. cDNA Synthesis}

RNA was converted to cDNA after treating with DNase I. Reverse transcription of RNA was done in a final volume of $20 \mu \mathrm{l}$ by using of cDNA first strand synthesis kit (Fermentase) random hexamere and $1 \mu \mathrm{g}$ of total RNA.
The samples were incubated at $65^{\circ} \mathrm{C}$ for $10 \mathrm{~min}$ and $42^{\circ} \mathrm{C}$ for $60 \mathrm{~min}$, and reverse transcriptase was inactivated by heating at $70^{\circ} \mathrm{C}$ for $5 \mathrm{~min}$ and cooling at $4^{\circ} \mathrm{C}$ for $5 \mathrm{~min}$.

\subsection{Real-Time RT-PCR}

Principle: Reactions are characterized by detection of cycling amplification of the PCR product, rather than the amount of PCR product accumulated after a fixed number of cycles. If the amount of the target molecule was larger, the earlier a significant increase in fluorescence is observed. The parameter $\mathrm{Ct}$ (threshold cycle) is defined as the cycle number at which the fluorescence generated by cleavage of the probe passes a fixed threshold above baseline. The details of qRT-PCR assay for determination of estrogen receptors mRNA level has been described in our previous work [10].

\subsection{Statistical Analysis}

$\mathrm{T}$ student test used to analysis the difference in serum level of adiponectin between obese and non-obese subjects. Pearson correlation coefficients were used to examine cross-sectional relationships between steroid hormone receptors expression and serum level of adionectin among subjects. All statistical analysis was conducted using SPSS statistical software (version 16). $\mathrm{p}<0.05$ were considered statistically significant.

\section{Results}

In this case-control study, 70 women with breast cancer participated with different grades of obesity (36 none obese, BMI $<25 \mathrm{~kg} / \mathrm{m}^{2}$ and 34 obese, BMI $\geq 25 \mathrm{~kg} / \mathrm{m}^{2}$ ). The mean age of Participants was $44.53 \mathrm{yr} \pm 1.79 \mathrm{yr}$ (ranged from 21 - 70 years old) and half of them were under 44 years old at the time of enrollment. Patients with previous history of radiotherapy or chemotherapy Excluded from this study our results indicated that there was a relationship between family breast-cancer history and obesity in breast cancer patients $(\mathrm{p}=0.01)$. Baseline characteristics are summarized in Table 1.

\subsection{Determination of Estrogen Receptors (ER $\alpha$ and $E R \beta$ ) Gene Expression in Breast Cancer Tissues}

The result of quantification of estrogen receptors gene expression described thoroughly in our previous work (10). According to the $\Delta \mathrm{CT}$ values, the mean mRNA level of $E R \alpha$ was $11.73 \pm 0.41$ in non obese cases vs 7.40 \pm 0.46 in obese ones and the mean mRNA level of ER $\beta$ was $8.01 \pm 0.53$ in non obese individuals vs $14.15 \pm 0.64$ in obese subjects (The higher $\Delta \mathrm{CT}$ values was an indication to lower mRNA level). Moreover, we find that obese subjects expressed a higher level of ER $\alpha$ in comparison 
Table 1. Characteristics of obese and non-obese breast cancer patient.

\begin{tabular}{|c|c|c|c|}
\hline Baseline characteristics & None obese $(n=36)$ Mean \pm SE & Obese $(n=34)$ Mean \pm SE & P value \\
\hline Age at enrollment (yr) & $43.82 \pm 1.78$ & $45.42 \pm 2.27$ & 0.45 \\
\hline BMI (kg/m²) & $23.23 \pm 0.23$ & $29.80 \pm 0.63$ & 0.000 \\
\hline Family history of Breast cancer & No. $(\%)$ & No. $(\%)$ & \\
\hline Yes & $18(54.5)$ & $6(22.2)$ & \\
\hline No & $15(45.5)$ & $21(77.8)$ & 0.01 \\
\hline \multicolumn{4}{|l|}{ Family history of obesity } \\
\hline Yes & $23(69.7)$ & $22(81.5)$ & \\
\hline No & $10(30.3)$ & $5(18.5)$ & 0.22 \\
\hline \multicolumn{4}{|l|}{ Menopause status } \\
\hline Premenopausal & $21(63.6)$ & $12(46.2)$ & \\
\hline Postmenopausal & $12(36.4)$ & $14(53.8)$ & 0.14 \\
\hline \multicolumn{4}{|l|}{ Age at first live birth (yr) } \\
\hline Less than 17 & $12(37.5)$ & $12(48.0)$ & \\
\hline $18-23$ & $11(34.4)$ & $10(40)$ & 0.32 \\
\hline More than 24 & $9(28.1)$ & $3(12)$ & \\
\hline \multicolumn{4}{|l|}{ Age at menarche (yr) } \\
\hline less than 12 & $10(30.3)$ & $6(23.1)$ & \\
\hline 13 & $5(15.2)$ & $10(38.5)$ & 0.12 \\
\hline More than 14 & $18(54.5)$ & $10(38.5)$ & \\
\hline
\end{tabular}

to non-obese subjects and the difference in ER $\alpha$ mRNA level between these two groups of patients was significant $(\mathrm{p}<0.001)$.In case of $\mathrm{ER} \beta$, the expression of $\mathrm{ER} \beta$ was lower in obese ones and the difference in $\operatorname{ER} \beta$ mRNAlevel between two groups was statistically significant $(\mathrm{p}<0.001)$.

\subsection{Correlation between Steroid Receptors and Serum Level of Adiponectin in Breast Cancer Patients}

We analyzed serum level of adiponectin in 70 breast cancer subjects. The mean serum level of adiponectin was $9.54 \mathrm{ng} / \mathrm{ml} \pm 0.44 \mathrm{ng} / \mathrm{ml}$. Obese subjects has a lower adiponectin in comparison to their lean counterparts $(8.33 \pm$ 0.48 vs. $10.61 \pm 0.66$ ) (Figure 1) .One tailed spearman coefficient test show that there was a significant reverse correlation between serum level of Adiponectin and ER $\alpha$ mRNA level $(\mathrm{r}=-0.229, \mathrm{n}=64, \mathrm{p}=0.035)$ but no correlation was between adiponectin and $\operatorname{ER} \beta$ in samples $(\mathrm{p}=$ 0.285) (Figure 2). We next considered the effect of serum level of adiponectin on the receptor mRNA status. The most relevant results from Chi-square test, revealed a significant relation between serum level of adiponectin and ER $\alpha$ gene expression ( $\mathrm{p}=0.02$ ). Table 2(a) shows that there was no difference in ER $\alpha$ mRNA expression in group with lower serum level of adiponectin, but in the group with moderate or higher level of adiponectin ,most of subjects expressed higher level of ER $\alpha$ gene $(81.2 \%$ vs $18.8 \%)$. Subjects with lower adiponectin $(\leq 7.02 \mathrm{ng} / \mathrm{ml})$ multiplied the odds of having higher $\mathrm{ER} \alpha \mathrm{mRNA}$ level by a factor of $\mathrm{OR}=4.33,1.28-14.6,95 \%$ confidence interval (CI) as compared with those that displayed a moderate or higher serum level of adiponectin $(>7.02$ $\mathrm{ng} / \mathrm{ml}$ ) and this difference was statistically significant ( $\mathrm{p}$ $=0.02$ ). The same odds for $\operatorname{ER} \beta$, was not greater than

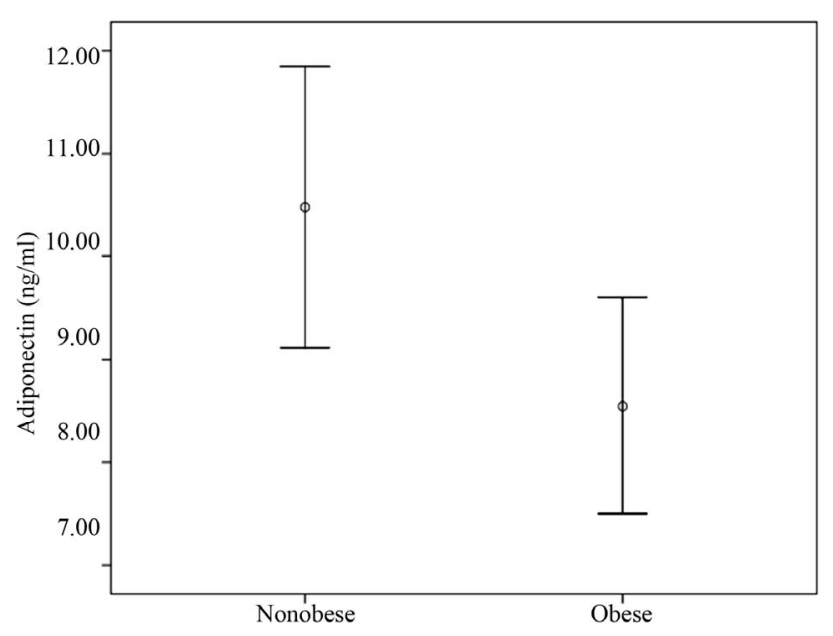

Figure 1. Mean serum level of adiponectin in obese and non obese breast cancer patients. 

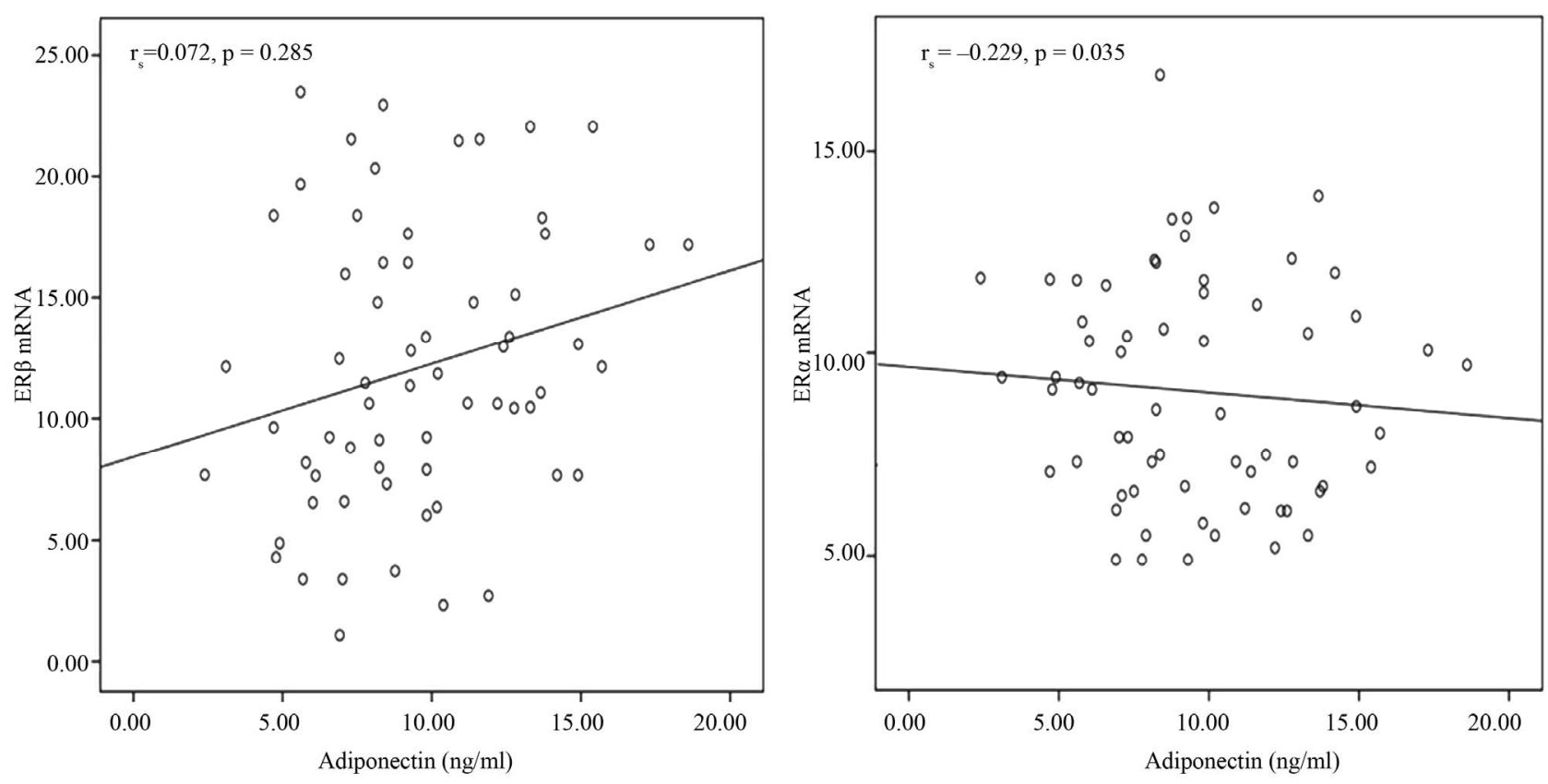

Figure 2. Correlation between estrogen receptors (ER $\alpha$ and ER $\beta)$ mRNA and adiponectin.

Table 2. Relation between serum level of adiponectin and estrogen receptors mRNA level in breast cancer patients.

(a)

\begin{tabular}{|c|c|c|c|c|c|c|}
\hline $\begin{array}{c}E R \alpha \\
m R N A\end{array}$ & Low & high & Total & $O R$ & CI 95\% & $\mathbf{p}$ \\
\hline low & $8(50.0 \%)$ & $8(50.0 \%)$ & $16(100.0 \%)$ & & & \\
\hline Moderate or high & $39(81.2 \%)$ & $9(18.8 \%)$ & $48(100.0 \%)$ & 4.33 & $1.28-14.6$ & 0.014 \\
\hline Total & 47 (73.4\%) & $17(26.6 \%)$ & $64(100 \%)$ & & & \\
\hline
\end{tabular}

(b)

\begin{tabular}{|c|c|c|c|c|c|c|}
\hline $\begin{array}{c}E R \beta m R N A \\
\text { Adiponectin }(\mathrm{ng} / \mathrm{ml})\end{array}$ & Low & high & high & Total & $O R$ & CI 95\% \\
\hline low & $14(87.5 \%)$ & $2(12.5 \%)$ & $2(12.5 \%)$ & & & \\
\hline Moderate or high & $33(68.8 \%)$ & $15(31.2 \%)$ & $15(31.2 \%)$ & 0.31 & $0.06-1.56$ & 0.19 \\
\hline Total & 47 (73.4\%) & $17(26.6 \%)$ & $17(26.6 \%)$ & & & \\
\hline
\end{tabular}

unity $(\mathrm{OR}=0.31,0.06-1.56,95 \% \mathrm{CI})$. Chi-square test show that there was no statistically significant relation between serum level of adiponectin and $\operatorname{ER} \beta$ gene expression in subjects $(\mathrm{p}=0.19)$ see Table 2 .

\section{Discussion}

According to the results of our previous works $[10,11]$ and the findings of this study we propose that affecting the estrogen receptor status is another mechanism of action of adiponectin that can affect prognosis of disease in breast cancer patients (see Figure 3). Far now many studied focused on antiproliferative and apoptotic effects of adiopnection on different breast cancer cell lines (16 - 18) (see Table 1). In one study by Marie-Noelle Dieudonne and his coworkers show that adiponectin represses c-myc and cyclin D1 mRNA expressions which strongly suggests that the inhibitory effect of this hormone on MCF-7 cell growth is due to a direct blockade of G1-S phase cell cycle progression (19). In addition, they observed that a simultaneous exposure to adiponectin and $17 \mathrm{~b}$-estradiol leads to suppress the mitogenic effect of $17 \mathrm{~b}$-estradiol on MCF-7 cells. Georg H. Pfeiler investigated adiponectin effects on human MCF-7, MDA 231 and T47D breast cancer cell lines. Like as Dieudonne, they demonstrate that E2 significantly reduces the AdipoR1 (adiponectin receptor) expression in ER $\alpha$-positive MCF-7 breast can- 


\section{A: Normal serum level of adiponectin (None obese subjects)}

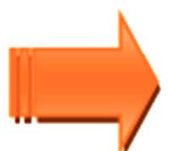

Normal ER signaling
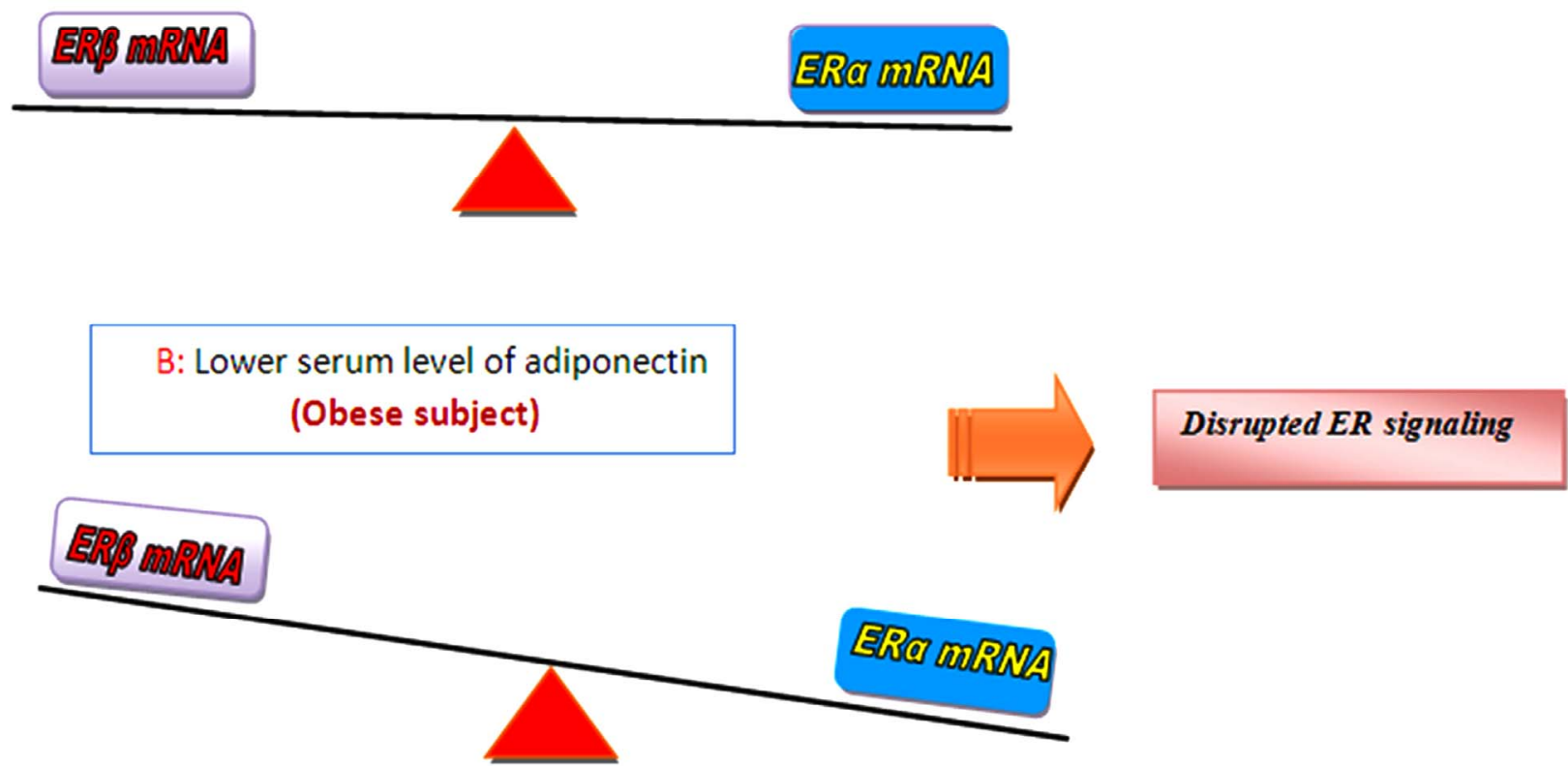

Figure 3. Proposed mechanism of action illustrate how serum level of adiponectin can affect ER signaling in obese breast cancer patients: Accumulating evidence show that serum level of adiponectin which act as a tumor suppressor gene strongly correlated with BMI and obese cases display lower serum level of adiponectin in comparison to their normal weight counterparts. According to the results of this study and previous works [17], it is tempting to speculated that adiponectin can put pivotal effects on estrogen receptor gene expression, at least by this proposed model that, A: Non obese cases have a higher serum level of adiponectin (in comparison to their obese counterparts) and so represent a higher expression of ER/ mRNA. Studies show that ER $\beta$ is dominant ER in normal breast and so ER signaling is normal is cases with normal serum level of adiponectin. B: At the other hand, obese cases frequently represent decreased serum level of this adipocytokine and display a higher expression of ER $\alpha$ mRNA as we observed in our study [11], from previous studies we know that mitogenic effects attributed to over expression of ER $\alpha$ and this receptor is the dominant ER in cancerous breast where the ratio of ER $\alpha / E R \beta$ increases and disrupt normal ER signaling.

cer cells. It is tempting to speculate that the E2-triggered down-regulation of AdipoR1 may be a signaling crosstalk directly affecting breast cancer risk (16). Even though Pfeiler et al were unable to show an effect of adiponectin on breast cancer cells alone, but they demonstrated that adiponectin significantly reduced the proliferation of MDA-MB231 breast cancer cells in an E2-enriched medium. In contrast to this, adiponectin further increased the proliferation of ER-positive MCF-7 cells. The combination of E2 and adiponectin increased the apoptotic rate in all three cancer cell lines (16). These divergent effects are difficult to explain because of the complicated hormonal signaling pathways. Finally, while treatment with adiponectin only affects the growth or apoptosis of breast cancer cells in the presence of estrogen, Pfeiler et al. propose that signaling crosstalk between the estradiol and adiponectin pathways may affecting the action of this adipocytokine on human breast cancer cells [16].
Treeck and his colleagues postulated that there is a cross talk between adiponectin and ER signaling. In their study on MCF-10A cells, adiponectin triggered a significant increase of ER $\beta 2$ and $\mathrm{ER} \beta 5$ mRNA levels [17]. The antimitogeneic activites of $\operatorname{ER} \beta$ attributed to $\operatorname{ER} \beta 2$ (also known as $\mathrm{ER} \beta \mathrm{cx}$ ) [9]. As ERa is known to mediate tumour-promoting effects of 17-b estradiol [18], they suggest that adiponectin-triggered increase of $\operatorname{ER} \beta$ isoform expression might be one important molecular mechanism underlying the protective effects of this adipocytokine [17]. We find out that lower serum level of adiponectin multiplied the odds of having higher ER $\alpha$ mRNA level by a factor of $\mathrm{OR}=4.33,1.28-14.6,95 \%$ confidence interval (CI) as compared with those that displayed a moderate or higher serum level of adiponectin. In this case we confirm findings of Pfeiler and Dieudonne [19] that as E2 can downregulate adiponectin receptor status but also serum level of this adipocytokin can affect expres- 
sion pattern of ER $\alpha$. In contrast to Treeck finding on MCF-10A, We find no correlation between ER $\beta$ gene expression and serum level of adiponectin, this controversy can be attributed to the different nature of samples (tissue vs. cell line) and also can refer to the evaluation of total ER $\beta$ in our experiment vs evaluation of special isoforms as Treek et al. considered in their study.

\section{Conclusion}

According to the obtained results, as adiponectin can affect ERs gene expression, so affecting the estrogen receptor signaling can be proposed as a new underling mechanism of action for this adipokine in breast cancer pathogenesis specially in obese subjects. In this study we were not able to show whether ER mRNA level could downregulate the serum level of adiponectin or not, so further studies require to clarify the possible effect. We speculate that serum level of adiponectin can affect estrogen receptors gene expression and so the pattern of ER positive or negattiveness and this in turn could affect the prognosis of disease in obese breast cancer subjects.

\section{Acknowledgements}

This work financially supported by Iranian National Science Foundation (INSF) with the ref code of 88000604 (April 12/2010). We appreciate all individuals who participated in this study.

\section{REFERENCES}

[1] A. Jemal, R. Siegel, E. Ward, Y. Hao, J. Xu, T. Murray, et al., "Cancer Statistics, 2008," CA: Cancer Journal for Clinicians, Vol. 58, No. 2, 2000, pp. 71-96. doi:10.3322/CA.2007.0010

[2] J. M. Holly and C. M. Perks, "Cancer as an Endocrine Problem," Best Practice \& Research Clinical Endocrinology \& Metabolism, Vol. 22, No. 4, 2008, pp. 539-550. doi:10.1016/j.beem.2008.07.007

[3] W. K. Hou, Y. X. Xu, T. Yu, L. Zhang, W. W. Zhang, C. L. Fu, et al., "Adipocytokines and Breast Cancer Risk," Chinese Medical Journal (English Edition), Vol. 102, No. 18, 2007, pp. 1592-1596.

[4] D. Housa, J. Housova, Z. Vernerova and M. Haluzik, "Adipocytokines and Cancer," Physiological Research, Vol. 55, No. 3, 2006, pp. 233-244.

[5] S. Loi, R. L. Milne, M. L. Friedlander, M. R. McCredie, G. G. Giles, J. L. Hopper, et al., "Obesity and Outcomes in Premenopausal and Postmenopausal Breast Cancer," Cancer Epidemiology, Biomarkers \& Prevention, Vol. 14, No. 7, 2005, pp. 1686-1691. doi:10.1158/1055-9965.EPI-05-0042

[6] M. Rahmati-Yamchi, N. Zarghami, M. Rahbani and A. Montazeri, "Plasma Leptin, hTERT Gene Expression, and Anthropometric Measures in Obese and Non-Obese Women with Breast Cancer," Breast Cancer, Vol. 5, 2011, pp. 27-35.

[7] J. Matthews and J. A. Gustafsson, "Estrogen Signaling: A Subtle Balance between ER Alpha and ER Beta," Molecular Interventions, Vol. 3, No. 5, 2003, pp. 281-292. doi:10.1124/mi.3.5.281

[8] V. Speirs, A. T. Parkes, M. J. Kerin, D. S. Walton, P. J. Carleton, J. N. Fox and S. L. Atkin, "Coexpression of Estrogen Receptor $a$ and $\beta$ Poor Prognostic Factors in Human Breast Cancer?" Cancer Research, Vol. 59, No. 3, 1999, pp. 525-528.

[9] C. Zhao, K. Dahlman-Wright and J. A. Gustafsson, "Estrogen Receptor Beta: An Overview and Update," Nuclear Receptor Signaling, Vol. 6, 2008, p. e003.

[10] R. Jahanban-Esfahlan, N. Zarghami, A. Jahanban Esfahlan, M. Mollazadeh, K. Nejati and M. Nasiri, "The Possible Impact of Obesity on Androgen, Progesterone and Estrogen Receptors (ER $\alpha$ and $\mathrm{ER} \beta$ ) Gene Expression in Breast Cancer Patients," Breast Cancer, Vol. 5, 2011, pp. 227-237.

[11] R. Jahanban Esfahla, N. Zarghami, M. Rahmati Yamchi, A. Monfaredan, et al., "Quantification of Steroid Receptors Gene Expression in Breast Cancer Patients: Possible Correlation with Serum Level of Adipocytokines," Journal of Cancer Therapy, in Press, 2011.

[12] M. Artac and K. Altundag, "Leptin and Breast Cancer: An Overview," Medical Oncology, 2011, pp. 1-8. doi:10.1007/s12032-011-0056-0

[13] B. Sonmez, M. Seker, A. Bilici, E. F. Yavuz, B. B. Oven Ustaalioglu, M. Gumus, et al., "Is There Any Correlation Among Adiponectin Levels in Serum, Tumor Tissue and Normal Tissue of the Same Patients with Breast Cancer?" Journal of BUON, Vol. 16, No. 2, 2011, pp. 227-232.

[14] W. Zhu, K. K. Cheng, P. M. Vanhoutte, K. S. Lam and A. $\mathrm{Xu}$, "Vascular Effects of Adiponectin: Molecular Mechanisms and Potential Therapeutic Intervention," Clinical Science, Vol. 114, No. 5, 2008, pp. 361-374. doi:10.1042/CS20070347

[15] I. Kelesidis, T. Kelesidis and C. S. Mantzoros, "Adiponectin and Cancer: A Systematic Review," British Journal of Cancer, Vol. 94, No. 9, 2006, pp. 1221-1225. doi:10.1038/sj.bjc.6603051

[16] G. H. Pfeiler, C. Buechler, M. Neumeier, A. Schaffler, G. Schmitz, O. Ortmann, et al., "Adiponectin Effects on Human Breast Cancer Cells Are Dependent on 17-Beta Estradiol," Oncology Reports, Vol. 19, No. 3, 2008, pp. 787-793.

[17] O. Treeck, C. Lattrich, I. Juhasz-Boess, S. Buchholz, G. Pfeiler and O. Ortmann, "Adiponectin Differentially Affects Gene Expression in Human Mammary Epithelial and Breast Cancer Cells," British Journal of Cancer, Vol. 99, No. 8, 2008, pp. 1246-1250. doi:10.1038/sj.bjc. 6604692

[18] J. D. Arditi, M. Venihaki, K. P. Karalis and G. P. Chrousos, "Antiproliferative Effect of Adiponectin on MCF7 Breast Cancer Cells: A Potential Hormonal Link between Obesity and Cancer," Hormone Metabolism Research, Vol. 39, No. 1, 2007, pp. 9-13. doi:10.1055/s-2007-956518 
[19] M. M. N. Dieudonne, M. Bussiere, S. E. Dos, M. C. Leneveu, Y. Giudicelli and R. Pecquery, "Adiponectin Mediates Antiproliferative and Apoptotic Responses in $\mathrm{Hu}-$ man MCF7 Breast Cancer Cells," Biochemical and Biophysical Research Communications, Vol. 345, No. 1, 2006, pp. 271-279. 